\title{
Czesław Miłosz „o sobie samym jako (o) innym”: Miłosz - Ricoeur
}

\author{
[...] czas jest tutaj czynnikiem odmien- \\ ności, oddalenia, różnicy
}

Paul Ricoeur ${ }^{\mathrm{I}}$

Dyskurs pamięci autobiograficznej wpisany w dzieło Czesława Miłosza² $^{2}$ można uznać za przykład ustanawiania „hermeneutyki siebie", czyli model podmiotowej egzystencji skonstruowany przez Paula Ricoeura w znanym studium $O$ sobie samym jako innym (2003)3. Aktywność polskiego pisarza na polu autobiografii, zauważana zwłaszcza w jego późnej twórczości, jest jakby odpowiedzią na swoisty nakaz albo na wezwanie francuskiego filozofa. Zagraniczny hermeneuta ujął swój postulat w następujące słowa: „Życie musi zostać streszczone, żeby mogło aspirować do miana prawdziwego życia. Jeśli mojego życia nie można uchwycić jako szczególnej całości, nie będę mógł nigdy pragnąć, by było ono udane, spełnione" 4 . Powstała triada utworzona ze słów kluczowych dla uchwycenia sensu niniejszej wypowiedzi Ricoeura: „streszczenie” - „całość” - „spełnienie”. Została przezeń odniesiona do egzystencji człowieka, którą w tym fragmencie swoich rozważań filozof nazwał po prostu: „życie”, ale kontekst tej części wskazuje na szerszy projekt, określany dalej w toku wywodu mianem „życia dobrego" ${ }^{5}$. Spoiwem dla wyszczególnionych pojęć mogą być teorie narratywistów ${ }^{6}, \mathrm{w}$ tym

I P. Ricoeur, O sobie samym jako innym, przeł. B. Chełstowski, oprac., wstęp M. Kowalska, Warszawa 2003, s. 195.

${ }_{2}$ Piszę o tym szerzej w książce: A. Rydz, Mnemozyna. O pamięci autobiograficznej w poezji polskiej, Poznań 2011. Tematyka tytułowa omawiana jest na przykładach twórczości C. Miłosza, J. Hartwig, Z. Herberta, W. Iwaniuka oraz M. Świetlickiego.

3 W nawiasach podano daty roczne publikacji dzieł Paula Ricoeura w polskim przekładzie.

4 P. Ricoeur, O sobie samym jako innym, przeł. B. Chełstowski, oprac., wstęp M. Kowalska, Warszawa 2003, s. 266.

5 Zob. P. Ricoeur, Dą̇enie do „życia dobrego”, w: O sobie samym..., s. 284-298 .

${ }^{6}$ Zob. K. Rosner, Narracja, tożsamość i czas, Kraków 2003. 
także samego autora Opowieści o czasie (2008). Jako nadrzędny został w nich wyrażony pogląd, wedle którego porządek rozwijanej opowieści buduje tożsamość tej opowieści bohatera. In nuce - chodzi o teoretyczne zjawisko definiowane zwykle jako „tożsamość narracyjna” 7 , kiedy to „[w]łaśnie tożsamość historii

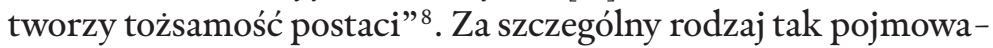
nej opowieści uchodzi skomponowana w dojrzałych latach życia autobiografia. Ricoeur piszac O sobie samym jako innym, zawarł tam również spostrzeżenie, które wydaje się szczególnie dogodne w sytuacji sędziwego Miłosza: człowiek „poszukuje swej tożsamości właśnie na szczeblu całego życia" ", a więc spoglądając na siebie przede wszystkim z perspektywy czasowej, z wysokiego dystansu minionych lat, by w końcu odszukać - jak to wyraził - „nieprzerwaną ciągłość w zmianie i w końcu trwałość w czasie, czyli to, co określa bycie tym samym” " ${ }^{\text {Io }}$ Innymi słowy - tożsamość osobową.

Również dla Miłosza pytania: „kim jestem?”, „kim byłem?” są ważne, albo raczej są podstawowe w jego pisarstwie. Czymże bowiem - jeśli nie roztrząsaniem losu, głównie własnego, ale także cudzego - pozostaje jego wielogatunkowa twórczość? W zasadzie już od chwili debiutu (Poemat o czasie zastygłym, 1933), że przypomnę $\mathrm{w}$ ten sposób tezę pionierskiego dla analizowanej problematyki artykułu Tomasza Burka pod tytułem Autobiografia jako rozpamiętywanie losu. Nie tylko o „Rodzinnej Europie” $(1981)^{\mathrm{II}}$. W tym miejscu należy poczynić pewne zastrzeżenie. Jakkolwiek dzieło Miłosza ujęte w formie totum zostało silnie nasycone pierwiastkiem autobiograficznym, problem tożsamości jego twórcy jako pilne, a nawet - powiedziałabym - naglące zadanie egzystencji, pojawił się przede wszystkim w utworach Starego Poety. Sprawa ta wysuwa się na plan pierwszy w późnych latach życia, gdy autor Kronik świętuje kolejne jubileusze: 85 lat, Na odwrót, Nie ma tego zlego (zapisy z tomu wspomnień: Piesek przydrożny, 1997), Późna dojrzałość, „JA”, Dziewięćdziesięcioletni poeta podpisuje swoje ksiazkki (przykładowe tytuły liry-

7 Proces ten zawansowany jest obecnie tak dalece, iż mówi się nawet o „medycynie narracyjnej” - zob. wywiad Olgi Woźniak z profesorem medycyny Andrzejem Szczeklikiem, Medycyna to sztuka rozmowy, „Gazeta Wyborcza”, 21 października 2011, s. 18.

${ }^{8}$ P. Ricoeur, O sobie samym..., s. 245.

9 Ibidem, s. 191.

ro Ibidem, s. 202.

II T. Burek, Autobiografia jako rozpamiętywanie losu. Nie tylko o „Rodzinnej Europie”, w: Poznawanie Mitosza 2. Część druga 1980-1998, red. A. Fiut, Kraków 2001. 
ków z lat 2002-2006), a przy tej okazji dokonuje podsumowania swojej domykającej się biografii.

Podmiot autorski zostaje wówczas jakby pochwycony w żelazny uścisk dialektyki, a uścisk ów Miłosz odczuwa szczególnie mocno i dotkliwie. Rzecz to znana, że „sekretnych trucizn manichejskich zjadacz" ${ }^{\text {I2 }}$ wykazywał od dziecka wrażliwość na dychotomiczne ujęcia ludzkiej egzystencji. Nim jednak wybije nań hora mortis, on także potrzebuje doprecyzowania własnego stanowiska w tej coraz bardziej naglącej kwestii. Przeto nie da się uciec od wzmożonej dialektyczności, napierającej teraz ze zwielokrotnioną siłą. Otwierający się przed „ja” rozdział rzeczy na „byt” i „niebyt”, „życie” i „śmierć”, „,istnienie” i „nieistnienie” zionie wówczas metafizyczną grozą, przed którą - zdawałoby się - na próżno komukolwiek szukać ratunku. W sytuacji bycia poetą egzystencjalny problem $\mathrm{z}$ istnieniem komplikują również artystyczne uwarunkowania mowy wiązanej: przekład indywidualnego doświadczenia na słowa, ograniczenia wprowadzane przez niewystarczalny język oraz osłabienie sił pamięci nierzadko kapitulujących przed zachłanną przeszłością, „bo to wszystko tylko mitologia - ani tak nie było, ani tak nie czułeś” (PP, 132, Pragnienie prawdy ${ }^{\mathrm{I}}$. Dodatkowo autor Doliny Issy (1953) szczególnie wyczulony jest na złożoność relacji tworzącej się między „ja” i bliźnim, między „ja” i wspólnotą czy - szerzej, uogólniając - między częścią a całością. Świadomy licznych aporii Miłosz podejmuje jednak próbę metafizycznej mediacji pomiędzy różnymi sferami ludzkiego doświadczenia, czego wyrazem jest na przykład Traktat teologiczny (w tomie Druga przestrzeń, 2002).

Pojęcie tożsamości osobowej w przywołanym studium Ricoeura (O sobie samym jako innym) opiera się na wyrazistej antynomii, rysującej się - jak mówi - „między charakterem (my sami jako idem) a stałością moralną, którą ilustruje obietnica (my sami jako ipse)" ${ }^{ }$. Jakie treści symbolizowane są przez użycia łacińskich zaimków w cytowanym fragmencie wypowiedzi? Idem oznacza wymiar psychofizyczny konstytucji ,ja”, zdeterminowany przez zapis genetyczny zawarty w helisie DNA albo

I2 Z. Kaźmierczyk, Dzieło demiurga. Zapis gnostyckiego doświadczenia egzystencji we wczesnej poezji Czestawa Mitosza, Gdańsk 2011.

I3 Cytowane dzieła Czesława Miłosza pochodzą z następujących edycji, które oznaczam odpowiednio symbolami: Piesek przydrożny, Kraków 1997 (PP); Redzinna Europa, Kraków 1994 (RE); Świadectwo poezji. Sześć wykładów o dotkliwościach naszego wieku, Warszawa 1990 (ŚP); Wiersze wszystkie, Kraków 2011 (WW); Zaczynając od moich ulic, Wrocław 1990 (ZMU); Ziemia Ulro, Warszawa 1982 (ZU). W nawiasie po przytoczeniu podaję numer strony, na której zlokalizowany jest cytat, oraz tytuł utworu, z jakiego on pochodzi.

I4 P. Ricoeur, O sobie samym..., s. 515. 
właśnie „charakter”, rozumiany jako stała predyspozycja do określonego typu zachowań. Natomiast tożsamość w sensie ipse („sobość”) ukształtowana zostaje z woli podmiotu przejawionej najpełniej w podjęciu działania. Zdaniem filozofa główną przeszkodą w rozwoju tożsamości osobowej jest bierne przeżywanie inności, szczególnie w trzech jej postaciach: w ciele, w spotkaniu $\mathrm{z}$ innym człowiekiem, w konfrontacji z własnym sumieniem, czemu znów odpowiada triada interpretowanych przez niego pojęć: „ciało” - „inny” - „sumienie”. Mówi zatem Ricoeur o „trójnogu bierności” ${ }^{\text {I5 }}$. Efektowna metafora zdaje się i tym razem odsyłać wprost do przekazu o antycznej Pytii, co służy sformułowaniu przestrogi dla współczesnych. Wystrzegać się więc należy uległości, jaką wobec przepowiedni wieszczki zachowywali przed wielu wiekami przybysze do starożytnych Delf. Równocześnie aluzyjna obecność wyroczni wprowadza w obszar naszych refleksji napis widniejący nad wejściem do dawnej świątyni Apolla: Cognosco te ipse. Zatem według Ricoeura trudna ta sztuka - rozumienia siebie samego - wymaga odkrycia w sobie wielowymiarowej inności jako prymarnego warunku osobistego rozwoju i możliwości osiągnięcia prawdy przez „ja”.

Pierwsza w żmudnym procesie stawania się jest tajemnica „ciała żywego”. Koniecznością pozostaje, żeby istota ludzka zaakceptowała w sobie obcość pochodzącą z zewnętrznego wobec niej porządku Natury. Warunek ów wystawia człowieka na próbę charakteru, zwłaszcza $\mathrm{w}$ stanach wszelakiego cierpienia ciała, w chorobie czy w niedołęstwie starości. Ale pamiętać warto i o tym, że ciało pozostaje przecież naturalnym pośrednikiem między wymiarem wewnętrznym podmiotu a światem sytuującym się poza jego granicami, na zewnątrz.

Okazuje się, że wcale nie mniejszym wyzwaniem dla formującego swe zręby „,ja” jest nauka niesiona przez „inność innego człowieka" ${ }^{16}$, a w zasadzie głęboko uświadomiona sobie przez nie „obcość” innego. Komentując taki stan rzeczy u Ricoeura, można by powiedzieć podobnie jak Clifford Geertz: „Obcość zaczyna się $[\ldots]$ na granicy skóry" ${ }^{17}$ i nie da się tutaj ominać ani raf cielesności, ani mentalnych różnic między ludźmi. Natomiast dla Emmanuela Levinasa „obcość” innego manifestuje się w epifanii jego twarzy. Przy tym stawanie się sobą kształtuje się

I5 Ibidem, s. 529. Filozof rozwija ten koncept w trzech częściach poświęconych kolejno zagadnieniom: Ciało własne lub ciało żywe (s. 530-546), Inność innego czlowieka (s. 546-567), Sumienie (s. 567-591).

I6 Ibidem, s. 546.

${ }_{7}$ C. Geertz, Zastane światto. Antropologiczne refleksje na tematy filozoficzne, przeł., wstęp Z. Pucek, Kraków 2003, s. 98. 
wprawdzie zgodnie z osobistym planem życia, ale zawsze w relacji do jakiegoś „ty”, ze względu na nieusuwalną obecność innego w polu naszych działań i w przedsiębranych indywidualnie projektach egzystencji. Kategoria działania, eksponowana przez Ricoeura w licznych pracach ${ }^{\mathrm{I}}$, jest więc tyleż niezbywalnym warunkiem, co końcowym probierzem aktywności człowieka w ustanawianiu więzi społecznej z kimś drugim (osobą, grupą, narodem). Wniosek końcowy przedstawia się następująco: tożsamość w sensie ipse to rodzaj etycznego zobowiązania, któremu nieodłącznie wtóruje postulat wzięcia odpowiedzialności za „ty”. Sam zaś podmiot zdefiniowany zostanie jako podmiot moralny.

Warto podkreślić przy tej okazji, że etyka nakłada na żywych szczególną powinność wobec zmarłych przodków. Już w samym fakcie pielęgnowania pamięci o nich - i bez względu na stopień łączącej nas z nimi zażyłości - zrealizowany zostaje model sumienia, który można określić, używając epitetu „pokoleniowy" I9, byłby on zresztą w terminologii Sigmunda Freuda, objęty nazwą superego. Respektowanie głosu przodków według francuskiego hermeneuty wyraża mądrość. W tym miejscu poczynił on uwagę, że prawidłowość ta dotyczy nie tylko najprostszego, ludowego przekazu, lecz łączy się z psychoanalizą. Konsekwencją stanowiska tego rodzaju będzie rozszerzenie koncepcji śladu pamięciowego z wymiaru teraźniejszego (rekonstrukcja przeszłości odbywa się bic et nunc) o przyszłość. Wobec powyższego poglądu filozofa, twórcom zasadnie może więc przyświecać nadzieja, że pozostała po nich spuścizna ocaleje, a stworzone dzieło oprze się próbie czasu i przetrwa ${ }^{20}$.

W świetle przekonania Ricoeura, iż literatura ,jest wielkim laboratorium dla doświadczeń myślowych" ${ }^{2 \mathrm{I}}$, a także ze względu na zajmowane przezeń stanowisko, wedle którego korelację kategorii działania $\mathrm{z}$ podmiotem ${ }^{22}$ najlepiej daje się pojąć na przykładzie rozpatrywania fikcji w dziele literackim, rzeczą naturalną, ba, oczekiwaną przez czytelnika jego prac, jest akces filozofa do narratywistów. Sam zaś aspekt narracyjny tożsamości osobowej został przez hermeneutę powiązany $\mathrm{z}$ wcześniej omówiony-

I8 P. Ricoeur, O sobie samym...; idem, Pamięć, historia, zapomnienie, przeł. J. Margański, Kraków 2006; idem, Miłość i sprawiedliwość, przeł. M. Drwęga, przedmowa J.L. Schlegel, Kraków 2010.

I9 P. Ricoeur, O sobie samym..., s. 588.

${ }^{\circ}$ P. Ricoeur, Żyć aź do śmierci oraz fragmenty, przeł. A. Turczyn, Kraków 2008, s. 135.

2I Ibidem, s. 263.

22 Charakterystyczny może być tutaj fragment: „Powiedzieć jestem to powiedzieć: chcę, poruszam, robię" (ibidem, s. 533). 
mi powinnościami „ja” względem Innego przy użyciu kolejnej triady słów: „opisać” - „opowiedzieć” - „nakazać” ${ }^{23}$.

Odnajduję w tych zaleceniach francuskiego myśliciela tematy Miłosza z jego późnej twórczości. Opisać ciało, jego „przygody” i sekretność przemian, którym ono bez ustanku podlega, opowiedzieć los własny i cudzy, nakazać pamięć o Innym - są to przecież sprawy żywo nurtujące autora tomu wierszy To (2000).

\section{Ciało}

Podstawą rozważań de se ipso i dla Miłosza, i dla Ricoeura jest czas. Tempus ciagle odmienia podmiotowe „ja”, oddala ,ja” od doświadczenia źródłowego, różnicuje czas na nieciągłe i punktowe części: „kiedyś” i „dziś”. Postawa polskiego noblisty wobec przemijalności jest oryginalna i daleka od wcale nie rzadko wystylizowanych studiów przygnębienia irytujących zwykle Miłosza jako przejaw literackiej mody, czy wręcz filozoficznej maniery ${ }^{24}$. Uczuciowy i poznawczy walor artystycznego przesiewania dokumentalnej warstwy życia przez autora Starego Poetę uzyskuje wartość przeciwną do obezwładniającej negacji, często spotykanej w dziełach twórców od niego młodszych. Wśród liryków Miłosza podejmujących ten temat są na przykład: Przepis, Tojasne, Przeciwoko poezji Filipa Larkina. Nieużalanie się nad sobą było dla poety przede wszystkim kwestią stylu, dobrego smaku, czy wyniesionej z domu kindersztuby. Charakterystyczna dla tej powściągliwej postawy pozostaje również zdeklarowana niechęć pisarza do Freudowskiej psychoanalizy, o której zwykł wypowiadać się tonem lekceważącym, lub nawet $\mathrm{z}$ jawną drwiną. Wymowny przykład braku zaufania dla nauk wiedeńskiego doktora zawarty został chociażby we Wstępie do Rodzinnej Europy (1958), gdzie pisarz roztrząsanie intymnych historii na forum literatury uznaje za przejaw „delektacji” i „pastwienia się” autorów nad sobą. Uważa, że z szacunku dla „piwnic” osobowości, które są w każdym, należy zmagazynowane w nich „ciemne” treści (najintymniejsze, raniące, zawiązane $\mathrm{z}$ popędową naturą człowieka) po prostu przemilczeć i unikać wydobywania ich na światło

23 Ibidem, s. 190.

${ }_{24}$ Zob. pierwszy z wykładów dla amerykańskich studentów (Zaczynając od mojej Europy), gdzie zostaje sformułowana diagnoza: „Dzisiaj myślę, że przewidywane apokalipsy mogą się zmieniać, ale nie nazwy nadawane niepokojowi są istotne, tylko szczególny stan umysłów, który wyszukuje powody rozpaczy doczepiane niejako ex post" (C. Miłosz, Śriadectwo poezji..., s. 19). 
dzienne ${ }^{25}$. Przekonanie to pozostaje $\mathrm{w}$ zgodzie $\mathrm{z}$ nadrzędnym poglądem poety o szkodliwości odsłaniania pokaleczonej psyche, która, zupełnie odwrotnie niż w klasycznej psychoanalizie, nie prowadzi wcale do uzdrowienia. W listopadzie 2002 r. autor jeszcze raz zabiera głos w tej sprawie, przy czym dobitnie wyraża swą dezaprobatę dla szczerości w literaturze: „Ponieważ ujawnione ludziom szkodzi” (WW, 1310, ${ }^{* * *}$ Nie wyjawiać...).

Symptomatyczny dla konsekwentnego stanowiska Miłosza w sprawie delectatio dolorosa jest też komentarz do Wierszy ostatnich (2006). Zebrane $\mathrm{w}$ pożegnalnym tomie utwory poeta uznał jedynie za skromne „[z]apisy mojego czucia że żyję, oddycham. Tym były moje wiersze więc hymnami wdzięczności. A razem z tym byłem świadomy nieszczęścia, skaleczenia. I nic we mnie nie było spontaniczne, ale pod kontrolą woli" (WW, 1301, ${ }^{* * *}$ Zapisy mego czucia...). Ostatecznie, efektem eksplorowania osobistego doświadczenia będzie w twórczości Miłosza „hymniczna” pochwała ludzkiego istnienia. Jednocześnie afirmująca postawa poety ogarnie również fenomen ziemskiego trwania, skonkretyzowany $w$ ramach jednostkowej biografii, o czym świadczy konstatacja: „Zestarzałem się w dziękczynieniu" (PP, 137, Osobny zeszyt - kartki odnalezione). Wielbienie życia, wyrażone w słowach - by tak powiedzieć - najprostszych z prostych (i podobnie do biblijnych psalmów oraz przysłów nieskomplikowane $\mathrm{w}$ warstwie leksyki), zostanie zakorzenione w codzienności poety, który odsłania swą prywatność, ale z zastrzeżeniem, że wyłącznie w granicach artystycznego warsztatu:

Na szczęście dalej w nocy układam wiersze

Choć kiedy zapiszę rano, nie mogę później odczytać.

Wspomagają mnie powiększone litery komputera.

Którego doczekałem, co już jest zaletą. (WW, 1245, Wiek nowy)

Pochwała komputera, niespodziewana, stanowiąca ewenement w kontekście nostalgicznego odbioru rzeczywistości, staje się głównym komponentem swoistej ody na cześć długowieczności. Autentycznym sukcesem jest dla człowieka - nieomal rówieśnika wieku XX oraz uczestnika dramatycznych zdarzeń historycznych minionego stulecia - już samo długie życie, skłaniające go do wdzięczności za „serie cudownych ocaleń” (WW, 1273, Żeby wreszcie). Przy okazji cieszy go również fakt doczekania technicznych udogodnień i umiejętność korzystania z nich. Ponad wszelką wątpliwość przebija $\mathrm{z}$ tych słów duma, tyle że

${ }_{25}$ Zob. C. Miłosz, Rodzinna Europa, s. 9. 
została ona zręcznie zakamuflowana pod warstwą nieśmiałej skargi na niedomagania fizyczne starości. Jednak nie ma tu śladu melancholijnej martwoty, pomimo dotkliwie odczuwanych ciosów, paradoksalnie zadawanych przez zdegradowane ciało będące w fazie nazywanej przez Miłosza „dojrzałą starością”, czyli gdy poeta był już „pod dziewięćdziesiątkę” i wkraczał właśnie w „wiek nowy”: „Ciało nie chce słuchać moich rozkazów./ Przewraca się na równej drodze, trudno mu wejść na schody" (WW, 1245, Wiek nowy). Toteż przyzywając na odsiecz odwieczną ironię ${ }^{26}$, bronił się Miłosz przed dokuczliwymi razami ze strony słabnącego organizmu. Figura retoryczna i tym razem, jak bywa najczęściej, będzie użyta w celu rozprawienia się $\mathrm{z}$ problemem albo całkowitego wyeliminowania go, tutaj - kłopotu z ciałem coraz bardziej pozbawianym siły i witalizmu. Na jej ostrze zostaną wzięte „, [w] szystkie parametry głębokiej starości” (WW, 1245, Wiek nowy). Oręż szacownej retoryki to prawdziwe dobrodziejstwo, które gwarantuje dystans, dzięki czemu można uzyskać „stosunek satyryczny” (WW, 1245, Wiek nowy) do własnej niedołężności.

Rzecz także i w tym, że w pisarstwie autora Rodzinnej Europy brak zgody na wizję człowieka wyabstrahowanego: bez związków z historią, sąsiedzką społecznością czy choćby z rodzimym krajobrazem. Więcej nawet, tylko fakt „sprawdzalny za pomocą pięciu zmysłów" (ŚP, 59, Lekcja biologii) uważany jest za podstawowy (dosłownie: „elementarny”), a poeta przedkłada go nad ekwilibrystykę myślową i wyraźnie faworyzuje. Zatem przymierze z ciałem okaże się nie tylko najtrwalszym związkiem zawartym „tu i teraz”, ale też prawdziwym wyznacznikiem kondycji człowieka - i w tej formie współtworzy nawet wyobrażenie zaświatów, owej „drugiej przestrzeni”, niczym w tytule zbioru wierszy wydanego w roku 2002.

Również odkrycie podobieństwa do Innego zostanie w twórczości Miłosza ufundowane przede wszystkim na epifanicznym oglądzie ciała: „Któregoś dnia, nagle, twarze doskonale znajome ukazywały się z piętnem przeżytych lat, pomarszczone, wyblakłe, o siwych włosach albo ze świecącą łysiną [podkr. A.R.]” (PP, 75, Ciepło). Zauważmy jednak, że tylko ciało niedoskonałe pod względem estetycznym, podległe prawu ziemskiego przemijania, staje się warunkiem nadchodzącego "w błysku” porozumienia z Innym. Braterstwo obudzone nieoczekiwanie we wspólnym przeżyciu starzenia się okaże się także formą bun-

${ }_{26}$ Zob. A. Legeżyńska, Gest pożegnania. Elegijność ironiczna w poezji końca wieku, w: Gest pożegnania. Szkice o poetyckiej śwwiadomości elegijno-ironicznej, Poznań 1999, s. 11-35. 
tu przeciw odzieraniu człowieka $\mathrm{z}$ indywidualności przejawiającej się w ludzkiej twarzy: „Ale tuż za nim krzątają się niewidzialne kosmetyczki Czasu, kładą cienie zmarszczek w kątach oczu, dorysowują ustom wyraz goryczy. Posypują popiołem włosy, zmieniają co własne w bezimienną maskę [podkr. - A.R.]" (WW, 1243, „JA").

Ciało poniżone w pisarstwie Miłosza zostaje skontrastowane $\mathrm{z}$ obrazami ciała w rozkwicie urody. Toteż opisy ciała własnego źródła narcystycznego zachwytu - przeplatają się nieustannie ze wspomnieniami ciała cudzego: obiektu pożądań, zazdrości, a równocześnie sensualnych bodźców dla estetycznej kontemplacji cielesnych obiektów w poezji. Natomiast w relacjach interpersonalnych między mężczyznami i kobietami upływ czasu niewiele może zmienić, przynajmniej $\mathrm{w}$ tej części twórczości Miłosza, która została obrysowana linią autobiografii ${ }^{27}$, bo jak sam poeta zauważył u schyłku życia - „i ciągle to samo, czyli stawką są wyobrażenia o sobie, o swojej urodzie, sile przyciągania, męskości, etc." (PP, 74, Nasza wespólnota).

Zdarza się i tak, że w refleksji Miłosza właśnie cielesność wyraża i wyobraża tajemnicę niewidzialnej łączności między światami żywych i umarłych. Sekretny proces odbywa się trochę na podobieństwo obrzędu znanego z Mickiewiczowskich Dziadów:

Jej ciało, które obróciło się w proch, jest dla mnie tak upragnione, jak było dla tamtego mężczyzny, i jeżeli dotykam jej we śnie, wcale nie mówi, że kiedyś umarła. Na pograniczu wielkiego odkrycia, przenikam już prawie sekret przemiany Poszczególnego w Ogólne i Ogólnego w Poszczególne.

Filozoficzne znaczenie nadaję chwili, kiedy pomagałem jej rozpiąć haftki gorsetu [podkr. - A.R.]. (WW, 789, Epigraf)

Widać zatem, iż elementy naturalistycznego opisu ciała nie tylko w przywołanym fragmencie, ale także w całościowo ujętej poezji autora Hymnu o Perle (1982) prowadzą zwykle do jakiegoś bardziej uogólniającego sformułowania. Droga przebiega tu w kierunku od rzeczy („haftki gorsetu”) do wyrażenia filozoficznej prawidłowości (,przemiany”). Przywodzi na myśl haiku, pisane przez mistrzów z Dalekiego Wschodu z takim oto zamys-

${ }_{27}$ O magnetyzmie, $\mathrm{z}$ jakim oddziałuje na kobiety mimo zaawansowanego wieku (i dumie odczuwanej z tego powodu), pisze Miłosz w sposób zaskakująco otwarty i wcale nie rzadko (np. w zbiorze wierszy Nieobjęta ziemia, 1984, czy w dzienniku Rok myśliwego, 1990). Zob. też A. Franaszek, Miłosz. Biografia, Kraków 2011. 
łem, „aby nasza dusza znalazła swoją nieskończoność w granicach jakiejś skończonej rzeczy" ${ }^{28}$.

\section{Inny}

Specyficznym odkryciem na skali indywidualnych emocji w biografii sędziwego Miłosza stała się odczuwana przez niego „[w] dziewiątej dekadzie mego życia” (PP, 163, Litość) przejmująca „litość” dla drugiego człowieka. Sens zacytowanego fragmentu wypowiedzi poety wskazuje raczej, że pod tą nazwą ukryta została wrażliwość, jaką dziś określilibyśmy najchętniej mianem empatii:

Mnóstwo, olbrzymia ilość twarzy, postaci, losów poszczególnych istnień i rodzaj utożsamienia się z nimi od ich wnętrza, a zarazem świadomość, że nie znajdę już sposobu, żeby tym wszystkim gościom ofiarować dom w moich wierszach, bo już za późno. Myślę też, że gdybym zaczynał na nowo, każdy mój wiersz byłby życiorysem albo portretem jakiejś konkretnej osoby, a ściślej lamentem nad jej przeznaczeniem [podkr. - A.R.]. (PP, 163, Litość)

Obecnie psychologia rozróżnia pojęcia „litość” i „empatia”. Pierwsza wskazuje na współczucie okazane komuś, na kogo spadają nieszczęścia, druga zaś dotyczy utożsamienia z kimś innym w dobrym i złym ${ }^{29}$. Myślę, że słowa Miłosza można by uznać za rodzaj „monologu empatycznego”, jak - za Dorrit Cohen nazywa Anna Łebkowska narrację, która zorientowana została na Innego, na współodczuwanie i współcierpienie $\mathrm{z}$ nim ${ }^{30}$. Lecz to uwikłanie w historię dwudziestowieczną stanie się dla Miłosza przede wszystkim rodzajem doświadczenia granicznego, które pozwoli temu autorowi na swobodne transgresje literackie w zakresie płci i czasu. Kulturowym „prototypem” takiej postawy jest postać Tejrezjasza, starożytnego profety $z \mathrm{Teb}^{3 \mathrm{x}}$. Pamiętamy, że dla bohatera greckiego mitu ujrzenie węży w miłosnym splo-

${ }^{28}$ Jest to pogląd H.R. Blytha, cytowany przez Czesława Miłosza zob. C. Miłosz, Haiku, Kraków 1992, s. 10.

${ }_{29}$ M. Davies, Empatia. O umiejętności współodczuwania, przeł. J. Kubiak, Gdańsk 1999.

$3^{\circ}$ A. Łebkowska, Empatia. O literackich narracjach przetomu XX $i$ XI wieku, Kraków 2008.

$3^{\mathrm{I}}$ Tejrezjasz wcielił się w postać żeńską oraz został przez jedną z bogiń obdarowany możliwością życia w siedmiu pokoleniach. Dla starożytnych nie mniej ważne było to, że w eposie Homera przewidział powrót Odyseusza na rodzinną Itakę (Homer, Odyseja, pieśń XI) - zob. W. Kopaliński, Tejrezjasz [hasło], w: Stownik mitów i tradycji kultury, Warszawa 1997, s. 1177. 
cie było aktem poznawczej inicjacji, a przekroczywszy granice tabu, posiadł on wiedzę o istocie męskiej oraz żeńskiej seksualności. Odwiedziny Wilna i okolic (realia świata przedstawionego w cyklu Litwa. Po pięćdziesięciu dwóch latach z tomu Na brzegu rzeki, 1994) są silnym przeżyciem emocjonalnym dla bohatera wierszy Miłosza, przypominającym doznanie psychicznego wstrząsu. Następstwem owego szoku jest epifaniczny ${ }^{32}$ odbiór „miasta młodości” przez przybysza, który pojawia się w nim po latach. W przedstawieniu zlewają się różne plany czasowe oraz wyłonione $\mathrm{z}$ nich postacie:

Męskosśc i żeńskość, minione, w nim się spotykały,

I każdy wstyd, każdy smutek, każda miłość.

Jeżeli nam dostępne rozumienie,

Myślał, to w jednej współczującej chwili,

Kiedy co mnie od nich oddzielało, ginie,

I deszcz kropel z kiści bzu sypie się na twarz

Jego, jej i moją równocześnie. (WW, 1063, Miasto młodości)

Zauważmy, że podstawą zachodzącej transgresji, zresztą nie tylko $\mathrm{w}$ przywołanej teraz cząstce poezji, będzie utożsamienie podmiotu mówiącego z lirycznym „ty”. Nadto w przestrzeń transgresji wpisana zostanie odwieczna tęsknota człowieka do osiągnięcia egzystencjalnej i epistemologicznej pełni. Pragnienie tego rodzaju wyrażone jest $\mathrm{w}$ symultanicznym łączeniu sprzeczności: męskość - żeńskość, rozumienie (ratio) - współczucie (emocje), oddzielenie - zjednoczenie, przeszłość teraźniejszość.

Ciekawa, jak sądzę, może być również następna obserwacja, mianowicie: narracja Miłosza uzyskuje walor empatyczności zwłaszcza wówczas, gdy podmiot mężczyzna odtwarza losy kobiet. W opowieściach tych odnajdujemy autobiograficzne ślady samego poety. Chodzi o dawne znajome $\mathrm{z}$ wileńskich lat jego biografii, przykładem może być tu postać Zosi z liryku Suknia w groszki, ale nie tylko. Poruszająca okaże się historia dawnej amantki, przechowana $\mathrm{w}$ pamięci podmiotu przez pół wieku, i to wbrew banalnemu rozpoczęciu (od sceny przypadkowego romansu jako faktu biograficznego). Dalsze losy bohaterki są jedynie odtworzone w serii domysłów „ja” wspominającego. Życie Zosi streszczone w wierszu zostanie domknięte tragiczną

$3^{2}$ Problematyka epifanii w poezji Czesława Miłosza doczekała się wielu komentarzy - zob.: J. Błoński, Mitosz jak śzwiat, Kraków 1998; A. Fiut, Moment wieczny. Poezje Czestawa Mitosza, Kraków 1998; R. Nycz, Literatura jako trop rzeczywistości. Poetyka epifanii w nowoczesnej literaturze polskiej, Kraków 2001. 
egzystencjalną pointą. Liryk mówi przecież o wilniance zmarłej w czasie II wojny światowej.

W galerii kobiet wykreowanych piórem Miłosza, opromienionych światłem nostalgii oraz empatią, nie brak też postaci o jawnie literackim rodowodzie. $\mathrm{Z}$ takim zabiegiem formalnym spotykamy się w „wierszu polonistycznym” zatytułowanym Rozbieranie Justyny. Utwór ten - będący czymś w rodzaju epilogu wierszem do dziewiętnastowiecznego eposu Elizy Orzeszkowej (Nad Niemnem, 1888), a dokładniej przyczynkiem do biografii powieściowej bohaterki - zręcznie żongluje tytułowym motywem rozbierania. Raz, traktując go jako wyznacznik sytuacji lirycznej, gdy młodziutka szlachcianka szykuje się do snu, a w lustrze pamięci ogląda jej rozebraną postać liryczny narrator, zatrzymujący na niej swój „,wzrok voyera”. Dwa, kiedy słowo „rozbieranie” uzyskuje sensy skojarzone z filologicznym rozbiorem tekstu $\mathrm{w}$ analitycznym procesie profesjonalnej lektury. Na koniec wyraz „rozbieranie” zmaterializuje się złowieszczo w politycznym rozbiorze „małej ojczyzny”, Wileńszczyzny Miłosza i Justyny, dokonanym przez potężnego totalitarnego sąsiada Polski i kładącym kres ziemiańskiemu światu „, białych dworków” oraz mieszkających w nim panien, matek i wdów.

Wniosek z omawianych przykładów płynie następujący: odpowiednikiem doświadczenia wprowadzającego w tajniki bytu było w przypadku poety osobiste doznanie burzliwej historii dwudziestowiecznej. W jej wyniku, jak mówił ustami alter ego: „Pomnożyłem się, zamieszkałem w każdej i w każdym równocześnie, a moja krótkotrwałość nie ma nade mną mocy [podkr. - A.R.]" (WW, 787, Haftki gorsetu).

Wariant motywu utożsamienia powraca w Wierszach ostatnich w formie modlitwy „Za nas, za nich i za mnie” (WW, 1326, Historie ludzkie). Poeta występuje w tym liryku w antropologicznym przebraniu szamana, jako przewodnik ludzkości czuje przede wszystkim odpowiedzialność za powierzony jego opiece ogół: „mam odprawiać moje rytuały/ Nieco powyżej, a nie poniżej człowieka" (WW, 1326, Historie ludzkie). Widać w tym postanowieniu konsekwencję, z jaką Miłosz nieprzerwanie przypisuje poetyckiemu słowu funkcję kerygamtyczną. Zresztą czy mogło być inaczej, skoro najczęściej (co nie znaczy, że zawsze) pokładał on ufność w „sile mowy” ? Wydaje się, że wiele z tego, co mówił, poruszając ten temat, daje się powiązać z refleksją nad możliwościami oraz ograniczeniami własnej pamięci:

To zdumiewające, myśleć o mnóstwie wydarzeń dwudziestego wieku i o ludziach tam występujących, rozumiejąc, że każda z tych 
sytuacji zasługiwała na epos, tragedię albo liryczny poemat. I nic, zapadały się, zostawiając nikły ślad. Można rzec, że najbardziej nawet potężna, krwista, czynna osobowość w porównaniu z celnym układem kilku słów, choćby opisywały tylko wschodzący księżyc, jest zaledwie cieniem. (PP, 61, Sita mowy)

Mając na uwadze powyższy fragment prozy z tomu wspomnień (Piesek przydrożny, 1997), można by stwierdzić, że konkluzja Miłosza na temat memorialny jest pesymistyczna. Literackie odwzorowanie czyichś dziejów zestawione $\mathrm{z}$ autentyczną biografią blaknie niczym cień. Jednak wartość pisarstwa osnutego wokół życiorysu tylko pozornie jest znikoma, musi wszak ustąpić przed obfitością egzystencjalnych zdarzeń. Mimo skłonności do ich zniekształcania $\mathrm{w}$ pamięci, poezja potrafi fakty te odtwarzać oraz poddawać interpretacji. Na tym polega ocalająca wartość poetyckiej mowy, ponieważ „[c]o jest nie wymówione, zmierza do nieistnienia [podkr. - A.R.]" (PP, 61, Siła mowy). Miłosz powtarza tę prawdę raz po raz.

\section{Sumienie}

W elegijnym nurcie twórczości Miłosza, wśród utworów poetyckich opublikowanych pod intrygującym tytułem To, znajdziemy na poły oniryczny, na poły konfesyjny, zapis wrażeń człowieka zbudzonego „w środku nocy” ze snu. Zostanie on wyrwany z onirycznej przystani nie dlatego, że męczą go senne majaki, ale $\mathrm{z}$ powodu doznanego tam wyciszenia umysłu i duchowej równowagi. Obudzony odbiera to doświadczenie jako przypływ niespodziewanego szczęścia:

\section{Spokój, który czułem, był spokojem zamknięcia rachunków i łączył się z myślą o śmierci. Szczęście po tej stronie było niby za- powiedź tego samego po drugiej stronie. Zdawałem sobie sprawę, że otrzymuję dar nieoczekiwany i nie mogłem pojąć, dlaczego spadła na mnie ta łaska [podkr. - A.R]. (WW, 1164, Obudzony)}

Te same motywy: indywidualnego szczęścia podmiotu, powinności moralnych, osobistego doświadczenia, napotkamy w projekcie etyki Ricoeura, wywiedzionym z Arystotelesowskiej phronesis ${ }^{3}$ (roztropności, mądrości praktycznej), którego osią teleologiczną będzie pojęcie i dążenie w podjętych dzia-

33 P. Ricoeur, O sobie samym..., s. 294. 
łaniach do „życia dobrego”. Francuski fenomenolog pamięci, przemodelowując tradycyjne kategorie wartościowania i oceny, upomniał się o moralność w rozumieniu sformułowanym przez Immanuela Kanta. Utrzymywał przy tym, iż nie ma „życia dobrego" bez zachowania szacunku dla uniwersalnych norm społecznych. W „przestrzeni autobiograficznej” 34 także Miłosz orientował się za pomocą aksjologicznej busoli, nierzadko obierając kurs w literaturze, ustawiając wskazówki w kierunku mikrokosmosu Litwy. Sam - wychowany przecież wśród guseł i wierzeń ludowych ${ }^{35}$, podobnie do narratora autobiograficznej opowieści Dolina Issy, chłonący w dzieciństwie barwne przekazy litewskiej społeczności - mógłby chyba podzielać stanowisko obcych mu psychoanalityków, w tym jednym i zarazem jedynym punkcie ich teorii,

wedle którego głos przodków nadal daje się słyszeć między żywymi i zapewnia w ten sposób nie tylko przekazywanie mądrości, lecz także jej wewnętrzne przyjmowanie na każdym etapie. Wymiar ten, który można nazwać pokoleniowym, jest niezaprzeczalnym składnikiem nakazu, a jeszcze bardziej - długu ${ }^{36}$.

Paul Ricoeur na zamknięcie rozważań $O$ sobie samym jako innym wybrał analizę zjawiska, które nazwać by można pokoleniowym modelem sumienia, a które to znajduje odzwierciedlenie w memorialnej twórczości Miłosza. Francuski filozof akcentuje antropologiczny wymiar metapsychologii Freuda, dochodzący do głosu $\mathrm{w}$ warstwie superego, czyli sumienia, gdzie zostają skrystalizowane przekonania autorytetów - rodziców i wcześniejszych przodków - wraz z kultywowanymi przez nich wartościami. Tym samym inność w sobie, po odkrytej wcześniej przez podmiot obcości ciała oraz Innego, zyskuje trzeci wymiar: upostaciowana $\mathrm{w}$ nieredukowalnej instancji sumienia ${ }^{37}$.

Walor upamiętnienia bliskich wysuwa się na pierwszy plan w utworach noblisty poświęconych przodkom. Retrospektywny odbiór osobistej przeszłości byłby przecież rażąco niepełny bez próby dotarcia do pokładów osobistej genealogii. Toteż pisarz wnikał w rodzinną historię wiele razy, na przykład w autobio-

${ }_{34} \mathrm{Ph}$. Lejeune, Wariacje na temat pewnego paktu. O autobiografii, red. R. Lubas-Bartoszyńska, przeł. W. Grajewski, S. Jaworski, A. Labuda, R. Lubas-Bartoszyńska, Kraków 2001, s. 52-55.

35 Zob. charakterystykę czasoprzestrzennej topografii doliny rzeki Issy na początku autobiograficznej powieści Czesława Miłosza.

${ }^{6}$ P. Ricoeur, O sobie samym..., s. 588.

37 Ibidem, s. 591. 
graficznych książkach: Dolina Issy czy Rodzinna Europa. W drugiej z nich autobiografia intelektualisty rozpoczyna się deklaracją: „Zaczynam eksplorację, wyprawę w głąb własnej, jednak nie tylko własnej, przeszłości” (RE, 7). Równie poczesne miejsce zajmuje tematyka związków familijnych w późnych zbiorach wierszy, pisanych już z perspektywy „podliczenia”, elegijnego bilansu życia ${ }^{3}$. W kolistych nawrotach wspomnień Miłosz rekonstruuje życie mężczyzn - przodków z linii Kunatów (Mój dziadek Zygmunt Kunat) i Syruciów (Pan Syruć), akcentując, że jego celem jest uwiecznienie zwykłych ludzi, których istnienie najczęściej przemilczają historyczne annały: „Ciepły dotyk policzków, wnętrza domów / I pojedyncze ludzkie żywoty, / O których kroniki nie opowiadają" (WW, 984, W muzyce).

Na kanwie dziejów swojego rodu - i może jeszcze bardziej zachowując świadomość, że w czasie historycznym, na jaki przypadła jego jednostkowa biografia, „wschodził wiek bezdomności" (PP, 161, Zamiast zostarić) - autor Ziemi Ulro przedstawił własną interpretację pomyślności losu. Słychać donośnie brzmiący głos Starego Poety, gdy wypowiada słowa przeznaczone dla Innego:

[...] wiedz, że możesz uważać się za szczęśliwego, jeżeli życie twoje układało się tak jak życie twoich sąsiadów. Jeżeli poruszałeś się, myślałeś, czułeś tak samo jak oni i tak jak oni dopełniałeś tego, co trzeba, w czasie właściwym. Jeżeli rok za rokiem obowiązki i obrzędy następowały po sobie, pojąłeś żonę, wychowałeś dzieci i spokojnie mogłeś spotykać ciemniejące dni starości [podkr. A.R.]. (PP, 308, Być takim jak inni)

Wobec „nieobjętej ziemi”, jej skomplikowanych spraw oraz złożoności ludzkiego istnienia Miłosz zaleca, aby zająć się tym, co naprawdę ważne, tym, co samemu można kształtować, a w czym on sam widział rdzeń egzystencji człowieka, czyli skromną „jako-takość” (WW, 818, ${ }^{* * *}$ Śnita mi się podróż...). Otóż głos usłyszany we śnie napominał poetę, aby przedmiotem twórczości uczynił ni mniej, ni więcej, tylko „codzienne życie, jakie-takie" (WW, 818, ${ }^{* * *}$ Śniła mi siępodróż...). W płaszczyźnie artystycznej odpowiadała obranemu tematowi szarej egzystencji człowieka „najbardziej pokorna sztuka mimesis” (ŚP, 82, Ruiny i poezja).

Z tych osobistych przekonań Starego Poety płyną też nakazy: „pochwalaj przeciętność”, „bądź takim jak inni” (PP, 308, Być

${ }^{8}$ Zob. A. Legeżyńska, Gest pożegnania... 
takim jak inni). Do pewnego stopnia powielają one szlachecki kanon zachowań, znany autorowi Doliny Issy z autopsji, z kresowych dworów, wśród których wzrastał. Właściwe temu środowisku dążenie do osiągnięcia złotego środka oraz bliski mu ideał poprzestawania na małym, są przez Miłosza rozumiane i wskazywane jako sedno życia. Pozostają również w identycznym stopniu zaleceniem i miarą szczęśliwej biografii człowieka. Rzec by można - stanowią one rodzaj adhortatio, retorycznej zachęty kierowanej przez pisarza do współczesnych pokoleń i do tych, które dopiero mają nadejść.

Ostatecznie projekt budowania tożsamości przez odautorski podmiot w późnej poezji Miłosza wykazuje kilka punktów przecięcia $\mathrm{z}$ kategoriami wypracowanymi przez Ricoeura $\mathrm{w}$ jego modelu hermeneutyki. Zbieżne $\mathrm{w}$ obu koncepcjach są: pojęcie długu zapośredniczonego przez współczesnych od minionych pokoleń, nakaz pielęgnowania pamięci o przodkach jako forma moralnej spłaty, a ponadto dążenie do osiągnięcia „życia dobrego" w realiach ziemskiej egzystencji. W ocenie autora Ziemi Ulro właśnie hołdowanie przekonaniom etycznym nadało sens jego istnieniu, jak ocenił bowiem, był „człowiekiem, który tak się urządza, żeby wierzyć w metafizyczne powody swego indywidualnego istnienia, czyli w to, że jeżeli żyje, to został zawczasu do czegoś powołany" (ZU, 268).

Próba opowiedzenia „o sobie jako (o) innym” pozwoliła Miłoszowi zredukować - zdawałoby się - nieusuwalną przepaść między podmiotem poezji a jej przedmiotem, między artystą a „rodziną ludzką" (ŚP, Poeci i rodzina ludzka) - ów kłopotliwy dlań spadek po modernizmie dziewiętnastowiecznym. Nie oznacza to jednak całkowitego zasypania owej wyrwy rozdzierającej analityczny umysł pisarza. Rozważania Miłosza o czasie minionym i sobie dawnym wprowadzają jednak dystans - konieczny, żeby móc na siebie spojrzeć okiem Innego. Wśród esejów z autobiograficznego tomu Zaczynając od moich ulic (1985) znajdziemy przecież i taką obserwację: „,jest to regułą życia wśród ludzi, że szata, jaką nosimy, pokazuje nas innymi, niż jesteśmy we własnych oczach" (ZMU, 386).

Zetknięcie się z innością reprezentowaną przez bliźnich nie pozostawia przecież podmiotu takim samym jak przed tym spotkaniem. Tożsamość kształtuje się w czasie. Tożsamość tworzy się w toku rozwijania opowieści. Wytrawny tropiciel pamię- 
ci, a był nim bez cienia wątpliwości autor Rodzinnej Europy, miał świadomość owych memorialnych i zarazem tożsamościowych reguł. Niejednokrotnie dawał temu wyraz w swojej bujnej, wielogatunkowej twórczości. To całkiem naturalne, że ten, kto teraz opowiada, jest przecież kimś innym od tego, kto przedtem przeżywał. Również w świetle ustaleń teoretyków relacja autobiograficzna nie jest imitacją autentycznego doświadczenia podmiotu pamięci. Nie tworzy kopii rzeczywistości. Powiedział kiedyś Miłosz, że „poeta żyje powtórzeniem” (WW, 377, *** W metrze paryskim kartki rozcinatem...) - dodajmy - w powtórzeniu.

Dokładnie 30 lat temu, w roku akademickim 1981/1982, polski noblista w zakończeniu wykładów dla studentów Harvard University „zdobył się” na pewną przepowiednię. Po XXI stuleciu spodziewał się radykalnego odwrotu od naukowego scjentyzmu, dlatego roztaczał przed swoimi słuchaczami wizję: „Ludzkość coraz bardziej będzie żywić się sama sobą, coraz bardziej będzie kontemplować swoją całą przeszłość, szukając w niej klucza do własnej zagadki i wnikając przez empatię w dusze minionych pokoleń i cywilizacji” (ŚP, 105, O nadziei). Zalecenie niniejsze wygląda tak, jakby zostało sformułowane na podstawie nauk wydobytych z obserwacji „siebie jako Innego”.

Miłosz nazbyt dobrze wiedział, że „[1]iryczni poeci/ Mają zwykle/ [...] zimne serca" (WW, 1299, Orfeusz $i$ Eurydyka), bo tego wymaga od nich kusząca dla każdego artysty doskonałość sztuki. Równie dobrze wiedział też, że tylko „intensywność” i „ciepło” kogoś naprawdę bliskiego, albo chociaż obecność Innego na horyzoncie egzystencji, może uchronić poetę od zagrażającej mu katastrofy w zderzeniu z „lodowcem wieczności” (PP, 75, Ciepto).

\section{AGNIESZKA RYDZ}

\section{Czesław Miłosz "On Oneself as Another": Miłosz - Ricoeur}

The article is thematically related to the fundamental essay by the French hermeneutic philosopher, On Oneself as Another, which discussed with reference to Miłosz's later writings (poetry and essays). The autobiographical quality of Miłosz's expression is discussed through the concept of "otherness" as presented by Ricoeur. The discussion is conducted in the framework of triple relation of a subjective "I": to one's body, to the Other, and to one's conscience. Miłosz, in his later works, responds to the ailings of the body with understanding, or even a sort of tenderness. Similar emotions are evoked by his contact with the Other, embodied by his ancestors and contemporaries. The responsibility for another person, however, and the communion with fellow people, 
are related, in his work, with the category of conscience. An attempt to narrate "oneself as another" allowed the Polish poet to reduce the seemingly irremovable rift between an artist and "the human family"; that rift was for Miłosz a troublesome legacy of modernism.

Keywords: Czesław Miłosz, memory, identity, Other, autobiographical writing.

Agnieszka Rydz - doktor habilitowana, adiunkt w Zakładzie Literatury i Kultury Nowoczesnej Instytutu Filologii Polskiej UAM. Zainteresowania badawcze: polska poezja dwudziestowieczna i najnowsza (po roku 1989) w kontekście szeroko rozumianej humanistyki. Autorka książek: „Świat nie ma sensu. Sens ma sztuka”. O powojennej poezji Kazimierza Wierzyńskiego (2004), Mnemozyna. O pamięci autobiograficznej w poezji polskiej (2011). Opublikowała również wstęp krytyczny do wyboru twórczości Stefana A. Borsukiewicza, Kontrasty. Powrót. Próba całości (2008).

e-mail: agryd@amu.edu.pl 